\title{
Comparative Study of Heavy Lead Pollution in Roadside Soil and Plants by Railway and Highway at Tangail District in Bangladesh
}

\author{
Arjun Chandra Bhowmick ${ }^{1, *}$, Md. Moustafijur Rahman Khan ${ }^{1}$, Majharul Islam Moim ${ }^{1}$, \\ Nikhil Chandra Bhoumik ${ }^{2}$, A.S.M Saifullah ${ }^{3}$ \\ ${ }^{1}$ Department of Chemistry, Mawlana Bhashani Science and Technology University, Bangladesh \\ ${ }^{2}$ Department of Chemistry, Jahangirnagar University, Bangladesh \\ ${ }^{3}$ Department of Environmental Science and Resource Management, Mawlana Bhashani Science and Technology University, Bangladesh
}

Copyright (C) 2015 by authors, all rights reserved. Authors agree that this article remains permanently open access under the terms of the Creative Commons Attribution License 4.0 International License

\begin{abstract}
This study explains the effect of heavy Lead pollution in soil and plants along the highway and railway of Tangail district. The metal concentration in soil and plant is decreased with increasing distance from the road of highway and railway. Lead is one of the most toxic elements. It is non-biodegradable and its toxicity does not change with time. Use of leaded gasoline in vehicles and train are known as the major source of lead pollution. Highway and railway of Tangail are two busiest routes of Bangladesh and pollution is rising day by day. To reveal the present situation in soil and plant samples were collected at various distances $(0 \mathrm{~m}, 15 \mathrm{~m}$, $30 \mathrm{~m}$ ) from Railway and highway roads and analyzed for lead by Atomic Absorption Spectrophotometric (AAS) method. The results show that the soil and plant samples along these places are contaminated with lead. The highest lead contents $0.1931 \mathrm{ppm}$ in soil and $0.1358 \mathrm{ppm}$ in plant was found for highway on road at $0 \mathrm{~m}$ distance. Conversely, the highest lead contents $0.0967 \mathrm{ppm}$ in soil and $0.0652 \mathrm{ppm}$ in plant was found for railway on road at $0 \mathrm{~m}$ distance. Among two types of major transportation system railway pollution is smaller than highway and hence railway transportation system is environment friendly.
\end{abstract}

Keywords Lead, Railway, Highway, Plant, Soil

\section{Introduction}

Owing to the increasing traffic volume pressures in urban areas, the environments that are closer to the highways are subjecting to pollution from traffic emissions. Many studies have proved beyond doubt that the urban roadside environments are polluted by heavy metals [1-3]. The metal pollutants, particularly lead and zinc accumulate, in the roadside soils [4] and are absorbed by invertebrate macro fauna [5] and vegetation [6]. Lead accumulates in the environment and being non-biodegradable does not lose its toxicity with time. Its presence in the environment is undesirable as it is known to affect the growth of children. The use of leaded gasoline in vehicles is the major source of lead pollution in cities, railway [7] and highways [8] around the world. Soil pollution by heavy metal (lead) is a problem of concern. Although heavy metals are naturally present small quantities in soil, contamination comes, from local sources: mostly industry (mainly non-ferrous industries, but also power plants and iron, steel and chemical industries), agriculture (irrigation with polluted waters, sewage sludge and fertilizer, especially phosphates, contaminated manure and pesticide containing heavy metals), waste incineration, combustion of fossil fuels and road traffic. Long-range transport of atmospheric pollutants adds to the metals in the natural environment. The dispersion of contaminants is influenced by meteorological conditions like wind, rainfall, profiles or by traffic intensity. The use of leaded gasoline in the transportation sector, especially in the automobiles, produces an increase in atmospheric lead concentrations to the extent that automobile lead emissions were the major source of lead $(60 \%)$ to the atmosphere [9]. Alkyl leads are extremely toxic, volatile, and unstable, and they are human health hazards at their sites of production [10]. These are often used as minor additives to gasoline and various auto-lubricants, and are released during combustion and spillage. Some of these metals are components of automobile parts such as tires and engines, from which they are released during abrasion and wears [11]. Public motor roads affects natural environment to a large extent because automobile act as line sources of heavy metal pollutants [12]. Excess of metal pollutants deposited on soils may be transformed and transported to vegetation [13] and from plants they pass on to animals and human being [14]. There have been several reports on road side soils pollution [15-19] by heavy metals 
close to some major cities. Heavy metals in the soil can also generate airborne particles and dust which may affect the quality of air. Inhalation of substantial quantities of heavy metal particles over period of time may add to human body and constitute health risk. This research is therefore to report on lead pollution in the roadside soil and vegetation at Tangail City in Bangladesh.

\section{Materials and Methods}

\subsection{Sampling Site}

Tangail is a district in the central region of Bangladesh (Figure 1). It is a part of the Dhaka Division. It is surrounded by the several districts, such as Jamalpur district on the north, the Dhaka and Manikgonj districts on the south, the Mymensingh and Gazipur districts on the east, and the Sirajganj district on the west .Tangail is connected with the rest of the country by both road and broad gauge rail line. Several intercity buses and trains are regularly operated through the route via Tangail. All samples were taken from central Tangail district highway and railway roads. This area beside the rail road, highway road section is an ideal area for studying the impacts of railway and highway road lead pollution in soil and plants.

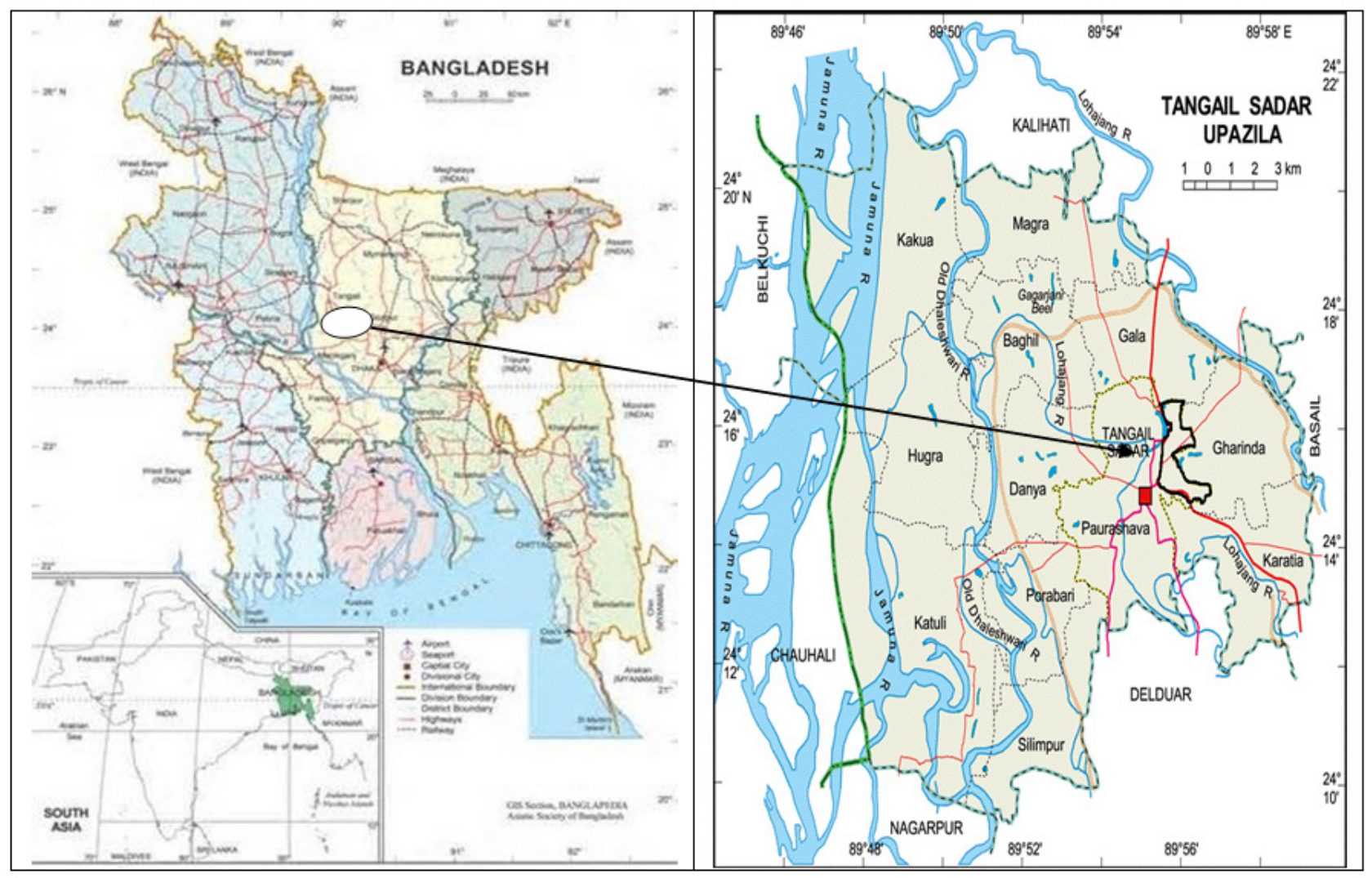

Figure 1. Study area on map of Bangladesh and Tangail district.

Table 1. The concentration of $\mathrm{Pb}$ in highway soil compared with railway soil.

\begin{tabular}{ccccc}
\hline Location & Sample Collection & $\begin{array}{c}\text { Distance } \\
(\mathbf{m})\end{array}$ & $\begin{array}{c}\text { Pd Conc. in highway } \\
(\mathbf{p p m} \text { or } \mathbf{~ m g} / \mathbf{L})\end{array}$ & $\begin{array}{c}\text { Pd Conc. in railway } \\
(\mathbf{p p m} \text { or } \mathbf{~ m g / L )}\end{array}$ \\
\hline \multirow{3}{*}{ Spot 1} & Road Soil (A) & $0 \mathrm{~m}$ & 0.1931 & 0.0967 \\
& Land Soil (B) & $15 \mathrm{~m}$ & 0.1013 & 0.0462 \\
& Land Soil (C) & $30 \mathrm{~m}$ & 0.0113 & 0.0038 \\
\hline
\end{tabular}

Table 2. The concentration of $\mathrm{Pb}$ in highway plants compared with railway plants.

\begin{tabular}{ccccc}
\hline Location & Sample Collection & $\begin{array}{c}\text { Distance } \\
(\mathbf{m})\end{array}$ & $\begin{array}{c}\text { Pd Conc. in highway } \\
(\mathbf{p p m} \text { or } \mathbf{~ m g} / \mathbf{L})\end{array}$ & $\begin{array}{c}\text { Pd Conc. in railway } \\
(\mathbf{p p m} \text { or } \mathbf{~ m g} / \mathbf{L})\end{array}$ \\
\hline \multirow{3}{*}{ Spot 1} & Road Soil (A) & $0 \mathrm{~m}$ & 0.1358 & 0.0652 \\
& Land Soil (B) & $15 \mathrm{~m}$ & 0.0829 & 0.0554 \\
& Land Soil (C) & $30 \mathrm{~m}$ & 0.0426 & 0.0329 \\
\hline
\end{tabular}



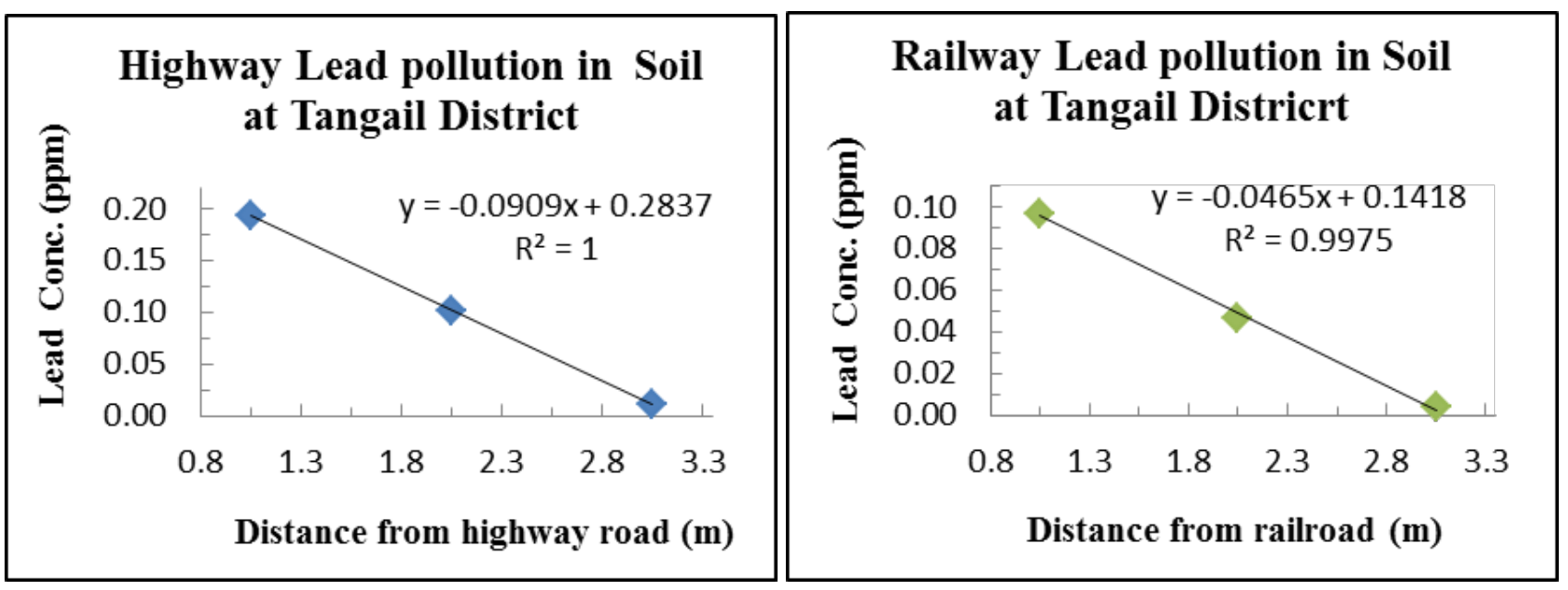

Figure 2. Highway and Railway Lead pollution in Soil at various distances

\subsection{Sample Collection}

Sampling for soil and vegetation was conducted on both road and broad gauge rail lines. The sampling section was located between Tangail City and Dhaka district. Plant and soil samples were collected at $0 \mathrm{~m}$ (on road), $15 \mathrm{~m}$ (from road), $30 \mathrm{~m}$ (from road) at each of the sampling sites. During plant sample collection it was selected small plants and their leaves. The collected soil samples $(0-15 \mathrm{~cm}$ depth) were tightly sealed in labelled polythene bags as soon as possible to avoid air exposure. The plant leaves were also sampled simultaneously at each place after each periodic collection. All collected samples were taken to the laboratory for further treatment and analysis.

\subsection{Sample Preparation}

After collecting the soil samples, the stones, gravels, pebbles, plant roots, leaves etc. were removed carefully and dried. The plants were washed with distilled water and dried on oven.

About $1 \mathrm{~g}$ of sample ( soil or plant) was accurately weighed and treated with $20 \mathrm{ml}$ of high purity concentrated nitric acid with $20 \mathrm{ml}$ of distil water and shake the mixture until the mixture was cooled. It was then refluxed for $1 \mathrm{~h}$ and cooled. Finally, the sample was filtered in $100 \mathrm{ml}$ volumetric flask by a filter paper (Whatmann No. 40) and the filtrates diluted to the mark $(100 \mathrm{ml})$ by distilled water. The procedure was repeated for all other samples and stored. All of the soil and plant samples was analyzed by AAS (Model: SHIMADZU AA-7000, Japan) and data were collected.

\section{Results and Discussion}

In the recent years huge number of vehicles is traveling on road in Gharinda bypass in Tangail district and no study has been done so far to investigate the effect of vehicle emissions on the roadside environment. This research, therefore reports on lead pollution in the roadside and railside soil and vegetation of Tangail City. In general heavy metal concentrations in soils and plants at the same site were found: Highway $\mathrm{Pb}>$ Railway $\mathrm{Pb}$. From Table 1 it is noted that at 30 $\mathrm{m}$ distance from road for both railways and highways pollution is small (Figure 2). We get the lead concentration in highway soil at $0 \mathrm{~m}$ distance, $15 \mathrm{~m}$ distance and $30 \mathrm{~m}$ distance $0.1931,0.1013$ and $0.0113 \mathrm{ppm}$ respectively. Conversely for railway soil at same distances are 0.0967, 0.0462 and $0.0038 \mathrm{ppm}$ respectively. Linear curves are plotted according to Table 1 and Table 2 and are shown in figure 2 and figure 3 respectively. From the figure 2 and figure 3 it is noted that experimental values fit well in the linear plot since $\mathrm{R}^{2}$ values are close to 1 .

From Table (2) we get the lead concentration in highway plant $0.1358,0.0829,0.0726 \mathrm{ppm}$, and railway plant 0.0652 , $0.0554,0.0329 \mathrm{ppm}$ from the distances $0,15,30 \mathrm{~m}$ respectively. According to Table 1 and Table 2 it is noted that the highest lead concentration for both soil and plant samples on road at $0 \mathrm{~m}$ distance and the lowest concentration is found at $30 \mathrm{~m}$ distance from road. It is also noted that from Figure 2 and Figure 3 the lowest pollution is creating by railway transportation system and it is an environmentally most friendly communication system. So, all types of vegetation should do far away from all types of road sides to avoid lead contamination in food. 


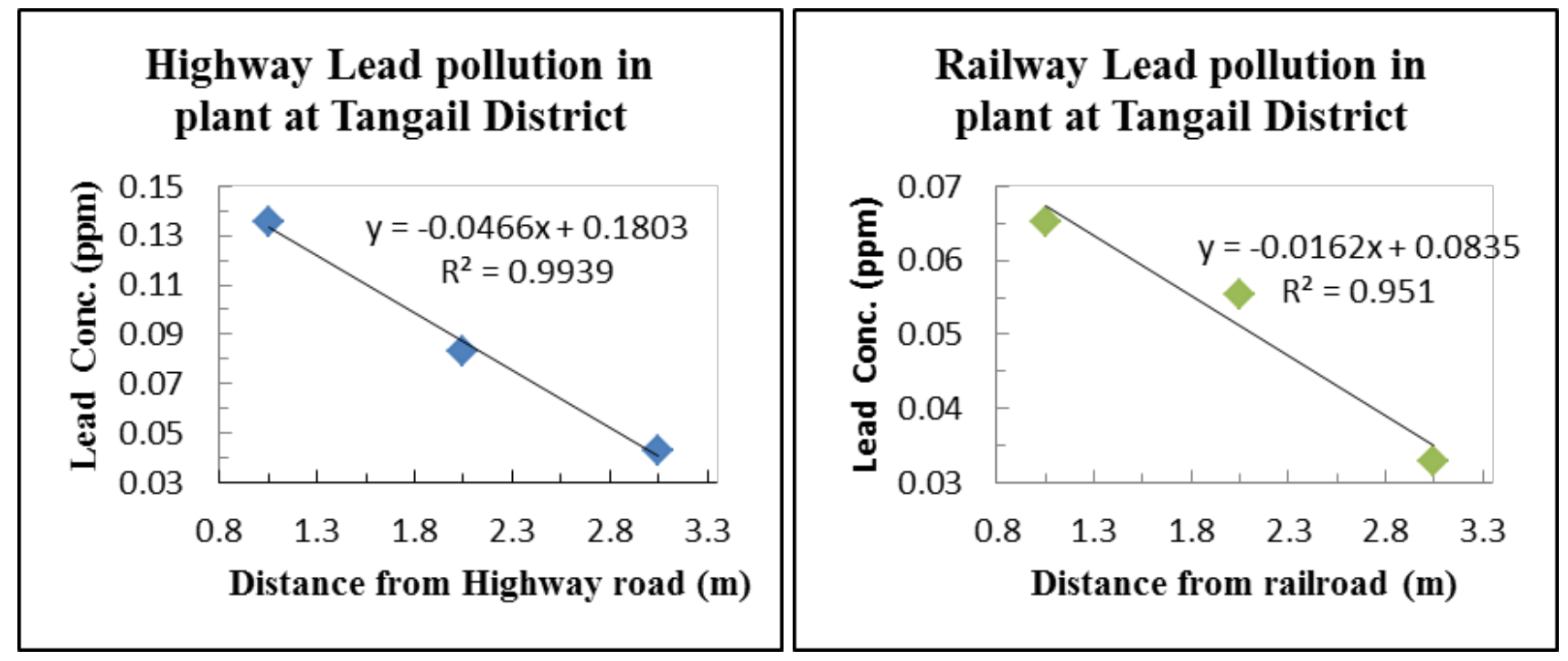

Figure 3. Highway and Railway Lead pollution in plant at various distances

\section{Conclusions}

It is noted from the research that the roadside soil and plants in Tangail district are highly contaminated by heavy lead when compared with the background values of WHO. The contamination is relatively higher than that of other places of residential areas. On road lead concentration is found highest than other sampling sites for both railway and highway. In addition to that heavy metal contamination for highway sides are higher than the railway sides. So, railway transportation system is more favorable than highway for reducing lead pollution. Since day by day vehicles are increasing in the route and this will be a threat for the locality in future if immediate care is not taken. Moreover, it is also important to omit of growing various vegetables, feeding domestic animals and others agricultural food items close to this district highway and railway road sides for reducing Lead contamination to them. It will be good if it is possible to ban all type of Lead containing gasolines.

\section{Acknowledgements}

I am very much grateful to my department of chemistry for supplying all research facilities during conduction of the research into my laboratory.

\section{REFERENCES}

[1] C. L. Ndiokwere. A study of heavy metal pollution from motor vehicle emissions and its effects on roadside soil, vegetation and crops in Nigeria. Env. Pollut. (Series B), vol. 7, $1984,35-42$.

[2] J. T. Nyangababo and J. W. Hamya. The deposition of lead, cadmium, zinc and copper from motor traffic on Brachiaria enimi and soil along a major Bombo road to Kampala City, Int. J. Env. Stud. Vol. 27, 1986, 115-119.

[3] I. Bhatia and G. N. Choudri. Impact of automobile effusion on plant and soil, Int. J. Ecol. and Env. Sc., vol. 17, 1991, 121-127.

[4] M. Rodriguez-Flores and E. Rodriguez-Castellon. Lead and cadmium levels in soil and plants near highways and their correlation with traffic density., Environ. Pollut. (Series B), vol. 4, 1982, 281-290.

[5] V. Pizi and G. Josens. The influence of traffic pollution on earthworms and their heavy metal contents in an urban ecosystem, Pedobiol. vol. 39, 1995, 442-453.

[6] K. Kunguru and P. M. Tole. Contamination of soils, maize, wheat,and milk with lead from motor vehicle emissions in Uasin Gishu District, Kenya. Disc. Innov. Vol. 3, 1994, 261-264.

[7] Hua Zhang, Zhaofeng Wang, Yili Zhang and Zhongjun Hu. The effects of the Qinghai Tibet railway on heavy metals enrichment in soils, Science of the Total Environment, vol. 439, 2012, 240-248.

[8] Azam Sadat Delbari and D. K. Kulkarni. Accumulation of heavy Metals in Vegetables Grown Along National High Ways-A Case Study of Tehran-Iran, International Journal of Engineering Science Invention, vol. 3. No.7, 2014, 77-82.

[9] J. O. Nriagu. Lead in the atmosphere. The biogeochemistry of lead in the environment. Elsevier/North Holland Biomedical press, Amsterdam, 1978, 137-184.

[10] P. S. I. Barry. Distribution and storage of lead in human tissues. The biogeochemistry of lead in the environment. Elsevier/ North Holland Biomedical press, Amsterdam, 1978, 97-150.

[11] A. R. Ipeaiyeda and M. Dawodu. Heavy metals contamination of topsoil and dispersion in the vicinities of reclaimed auto-repair workshops in AWO, Niegeria. Chemical Society of Ethiopia, Bull. Chem. Soc. Ethiop. vol. 22, no. 3, 2008, 339-348.

[12] Poszyler-Adamska, A and A. Czemiak. Biological and 
chemical indication of roadside ecotonic zones. L. Environ. Engg. Landscape Management, vol. 15, no. 2, 2007, 113a-118a.

[13] M. O. Atayese, A. I. Eigbadon, K.A. Oluwa and J. K. Adesodun. Heavy metal contamination of amaranthus grown along major highways in Lagos. Afr. Crop. Sci. J., vol. 16, 2009, 225-235.

[14] K. Suzuki., T. Yabuki and Y. Ono. Roadside Rhododendron pulchrum leaves as bioindicators of heavy metal pollution in traffic areas of Okayama. Japan. Environ.Monit. Asses., vol. 149, 2008, 133-141.

[15] E. S. Abechi., O. J. Okunola, S. M. J. Zubairu, A. A. Usman and E. Apene. 2010. Evaluation of heavy metals in roadside soils of major streets in Jos metropolis, Nigeria. Journal of
Environmental Chemistry and Ecotoxicology, vol. 2, no. 6, 2010, 98-102.

[16] H. M. Naser., S. Sultana, R. Gomes and S. Noor. Heavy metal pollution of soil and vegetable grown near road side at Gazipur Bangladesh, J. Agril. Res., vol. 37, no. 1, 2012, 9-17.

[17] S. S. Ahmad and S. Erum. Integrated assessment of heavy metals pollution along motorway M-2.Soil \& Environ., vol. 29, no. 2, 2010, 110-116.

[18] M. Qasem and A. Kamal. Contamination of Roadside Soil, Plants, and Air with Heavy Metals in Jordan, A Comparative Study., Turk J. Chem., vol. 23, 1998, 209-220.

[19] H. Arslan and A. Murat. Heavy metal content of roadside soil in Mersin, Turkey. Fresenius Environmental Bulletin, vol. 15 no. 1, 2006, 15-20. 